\title{
NOMENCLATORIAL NOTES RELATING TO BRITISH NON-MARINE MOLLUSCA.
}

By A. S. Kennard, F.G.S., and B. B. Woodward, F.L.S.

Read 14th May, 1920.

\section{Testacella.}

THE history of this genus was well summarized by Gassies and Fischer in 1856 in their "Monographie du genre Testacella" (Actes Soc. Linn. Bordeaux, xxi, pp. 195-248), whilst in December, 1861, Bourguignat published, by way of a supplement, his "Notice sur les espèces vivantes et fossiles du genre Testacella" (Rev. \& Mag. Geol., sér. II, tom. xiii, pp. 513-24.-Reïssued in his Spiciléges Malacol., 1862, pp. 55-68). These two papers, however, were not, of course, conceived as regards nomenclature in the same light that obtains to-day, and hence modifications in their conclusions have become necessary, especially with regard to the three species present in Britain, with which alone we propose to deal.

A brief summary of the history of the genus, drawn mainly from Gassies \& Fischer, is necessary to the understanding of the case we present.

1740. The first published notice of these molluses seems to have appeared in 1740, when a M. Dugué wrote from Dieppe to Réaumur concerning the discovery in his garden of a slug carrying on its hinder end a claw-shaped plate. (Hist. Acad. Sci. Paris, 1740 [1742], pp. 1 and 2.)

1754. In this year it is said that a M. La Faille, of La Rochelle, made a similar communication to Guettard, but his observations were not published.

1774. La Faille seems to have sent Favanne a specimen in spirit, attributing the discovery to Dr. Guillemeau, of Niort.

1779. The Viscount De Querhoent, of Le Croisic in Brittany, wrote to Valmont de Bomare detailing the exhumation by his gardener, in October of that year, of a slug which was preying upon, and had partly swallowed, a worm. (Dict. rais. univ. Hist. Nat., ed. 4 , tom. iv, 1791 , p. 579.)

1780. Favanne de Montcervelle and his son when producing the third edition of Dezallier d'Argenville's "Conchyliologie", appended a series of plates under the title of "Traité de la Zoomorphose". Here on pl. lxxvi they depicted certain "Limaces à Coquilles ", one of which may well have been taken from the specimen received as above recorded from La Faille, although no mention is made thereof.

1796-98. By order of the French Government an expedition to the islands of Teneriffe, La Trinité, Saint-Thomas, Sainte-Croix, and Porto Rico, under the command of Capt. Baudin, was sent out 
in 1796, returning in 1798. R. Maugé was the zoologist and Le Dru botanist. The collections they brought back were deposited in the National Museum, but owing to Maugé's decease and other causes were not worked out (Gass. \& Fisch., p. 199). Notes concerning them were published in Le Dru's account of the voyage in 1810 , to be cited later.

1800. Cuvier instituted the name Testacella, which appears, without any definition or description whatever, on Table $V$ of his "Leçons d'Anatomie Comparée ", tom. i.

1801, January. Lamarck, who had evidently become acquainted with Maugé's specimen (or specimens) from Teneriffe, preserved in the Natural History Museum at Paris, accepted the name Testacella, and gave a description of the genus, citing after the custom of the time the nearest figures, which were those of Favanne, and giving as examples (Syst. Anim. s. Vert., p. 96) : "Testacella haliotoides. n. ex $D$. Mauger [sic] ex ins. Teneriffæ.'"

Since " a genus proposed with a single original species takes that species as its type" (Internat. Rules Zool. Nomencl. Monaco, 1913, Art. 30, I, c), and in such cases the generic description obviously covers the species and is rightly held to do so (opinion 43), Lamarck's name, which is correctly formed, cannot be set aside as a nomen nudum, but must hold for the sole species of Teneriffe, afterwards renamed by Férussac Testacella maugei.

About this time a M. Faure-Biguet rediscovered the genus in France, and supplied Draparnaud and Cuvier with specimens, as stated by the latter in his paper presently to be referred to.

1801, July. So that in his "Table des Mollusques terrestres et fluviatiles de la France ", which appeared in July, 1801, Draparnaud was able to include the form under the generic name of Testacella, adding in a note (p. 99): "Il faut rapporter au genre Testacelle, les limaces à coquille de Favanne . . . qui sont toutes exotiques, et de l'île Ténériffe, selon Mauger [sic]." Apparently unacquainted with Lamarck's work, but similarly struck by the resemblance of the shell to that of Haliotis, he bestowed on the species the philologically incorrect name of haliotidea. His name, therefore, being a homonym of Lamarck's, cannot stand, although it has so long been in use.

1802. Early in the year Bosc, who was evidently unacquainted with Draparnaud's work, gave in his "Histoire Naturelle des Coquilles" (suites à Buffon classé par Castel), tom. iii, p. 240 (under Testacella, Lamarck) T. haliotoides, from Teneriffe, $T$. costata, from the Maldives, and T. cornina, locality unknown.

1802, March. Faure-Biguet published a note, "Sur une nouvelle espèce de Testacelle" (Bull. Sci. Soc. Philom. Paris, An x, p. 98, pl. v, f. [2] A-D), describing and figuring the form named $T$. haliotidea by Draparnaud, but himself giving no name of any sort, nor locality. 
1805, February. Cuvier (Ann. Mus. Hist. Nat. Paris, v) described and figured the animals sent him by Faure-Biguet and their anatomy, under the name (p. 440, pl. xxix, f. 6-11) "La testacelle de France (testacella haliotoidea [sic], Drap.)". His figures leave no doubt as to the species with which he was dealing.

1805, June. Roissy (Hist. Nat. Moll.: Suites à Buffon rédig. Sonnini, v), in dealing with the genus Testacella, proposed (p. 252) the name of $T$. europcea for the French form, cited Faure-Biguet's paper, and remarked that that writer gave it as occurring in the south of France, whilst Draparnaud recorded it from the north of France. He ignored Draparnaud's name of haliotidea, and overlooked Draparnaud's record of its occurrences both in northern and southern France. Roissy's further species are T. cornina, without stated locality, $T$. haliotoïdes, from Teneriffe, and $T$. costata from the Maldives. For the reasons already given Roissy's name europcea will stand in lieu of Draparnaud's haliotidea.

1805. Late in 1805 Draparnaud (Hist. Moll. France, p. 121, pl. viii, f. 43-48; ix, f. 12-14) repeated his name of Testacella haliotidea unsupported by any references. We are sceptical concerning the suggestion that the shells figured on pl. viii, f. 46-48, as of the adult animal should be referred to $T$. maugei.

1807. Férussac (Essai méthod. Conchyl., p. 41) enumerated four species: (1) Testacella haliotidea, Faure-Biguet (an error as to the author of the species which was afterwards frequently copied); Cuvier and Draparnaud are also cited, and Roissy's T. europcea correctly placed as a synonym.

(2) $T$. cornica [sic], Roissy. $T$. haliotoïdes, Roissy, Teneriffe. (4) T. costata, Roissy. In the "Concordance systématique" (p. 116) only T. haliotidea appears.

1810. Ledru's account of the expedition of 1796-8 (Voy. aux Îles de Teneriffe, La Trinité, etc., tom. i, p. 187) by a printer's error gives another spelling for the name of the Teneriffe species, viz. "Testacula haliotoides ", Roissy's version being evidently intended.

1819. Férussac (Hist. Nat. Moll., ii, p. 94), following Montfort (1810), changed the form of the generic name to the masculine and cited Testacellus haliotideus, Faure-Biguet (pl. viii, f. 5-9, 11, 13-15), with other references as before, and T. mangei, nobis (pl. viii, f. 10 and 12) with $T$. haliotoïdes, Lamk., as synonym. A repetition of these occurs in his later Tabl. Syst. des Limaces, 1821, p. 26, with the synonyms added to the former species of Testacella europaea, Roissy, T. halioidea, Drap., and T. gallice, Oken.

1822, April. Lamarck (Hist. Anim. s. Vert., vi, pt. 2) so far underrated his original species as to say (p. 51) "Il n'y a encore quel'espèce suivante qui soit bien connue ",-, namely (p. 52) Testacella haliotidea, which he attributes to Faure-Biguet, whilst citing Draparnaud, Férussac, and Cuvier.

1831. Michaud, late in 1831 (Complément Hist. Nat. Moll. France de Draparnaud, p. 9), furnished an example of careless 
copying without reference to the original source when under Testacellus haliotideus he added "J'ai cru devoir conserver à ce genre le véritable nom qui lui avait été imposé par Faure-Biguet, Bull. Soc. phil. No. 61 ", which reference he obviously took from Férussac.

1855. Grateloup (Distrib. géogr. fam. Limaciens, pp. 15 and 16), not satisfied with the existing names of the species, superfluously suggested others, and even for maugei two other names.

From the foregoing, therefore, it becomes apparent that the three British representatives of the genus should be known as :-

\section{Testacella haliotoides, Lamarck. T. maugei, Férussac. \\ 2. europcea, Roissy. T. haliotidea, Draparnaud. \\ 3. - scutulum, Sowerby.}

The more extended synonymy may be reserved for another occasion. Several Continental forms of Testacella have been described at different times and attempts have been made to reconcile these with one or other of the above species. Until, however, much more complete knowledge of these is to hand it seems better to treat them as distinct after the manner of Gassies \& Fischer, and of Bourguignat, than to guess at their possible affinities. More especially should species founded on imperfectly preserved fossils, some of which date back to the Miocene, be severely let alone.

MM. Gassies \& Fischer concluded their monograph with a list of thirteen species which have been included in, but do not belong to, the genus Testacella. Strangely enough the twelfth is a myth of their own manufacture. "Testacella teneriff $\propto$, D'Orb., père inéd. in Fér." resolves itself in the original (Férussac, Hist. Nat. Moll., ii, p. 87) into "Description communiqué par Mr. d'Orbigny sous le nom de Testacelle de Ténériffe", Férussac's own name for the animal being Plectrophorus orbignii. Liberties of this sort give an infinity of trouble to the student. Moreover, apparently by misreading d'Orbigny's statement (in Webb \& Berthelot, Hist. Nat. Îles Canaries, tom. ii, pt. 2, 1839, p. 49) that Testacella haliotidea, Drap., occurred "dans l'île Canarie" [i.e. in Grand Canary] as "dans les îles Canaries", or the archipelago generally, they concluded that it occurred in Teneriffe also, which it seemingly does not, and proceed to make deductions therefrom that cannot be maintained. Orbigny's opinion was that maugei, Fér., was a climatal variety of haliotidea, Drap.

Helix acuta, Müller.

We have recently maintained (Journ. Linn. Soc. (Zool.), xxxiv, 1920, pp. 206-207) that Linné's name of Helix barbara must be 
allowed to lapse on account of ambiguity, ${ }^{1}$ and favoured a return to Müller's name of acuta for the British species; and it is still our opinion, as it was that of Dillwyn (Cat. Shells, ii, 1817, p. 956), that this is correct.

Considerable controversy raged in the past as to the correct use of Müller's name, and to judge from a quite recent memoir divergent views still persist, so that it seems desirable to review the question yet once again in the light of modern zoological rules and requirements.

By way of prelude it is necessary to refer to certain cited figures on the interpretation of which a good deal depends. Lister, in his "Historiæ sive Synopsis methodicæ Conchyliorum ", on pl. xix, fig. 14, gave an unmistakable representation of our British species, naming as localities: "Gall. nar. [= south-eastern France] Aldernensi Insula. A. [= Anglia]. Wallia. Flord." Then there are three sets of figures on pl. iv of Gualtieri's "Index Testarum Conchyliorum ". Of these "I" manifestly represent the English shell, "L" a shell with a strongly marked lip that can have nothing in common with ours, and " $\mathrm{N}$ " a pair that might be held to represent young and rather tumid examples of " I", but do not resemble in shape or proportions the Bulimus ventricosus of Draparnaud.

Müller, in his "Vermium Historia ", ii, 1774, p. 100, gave all too brief diagnosis of his Helix acuta, but he cited Gualtieri's fig. " $\mathrm{N}$ " and Lister's fig. 14. This last, with the dimensions "long. 4 lin. lat. $1 \frac{1}{2}$ lin.", in our opinion, determines his species to be the form that has so long borne the name. Gmelin in 1791 (Linn. Syst. Nat., ed. 13 , i, pt. 6 , p. 3660) merely followed Müller.

Bruguière next, in 1789 (Ency. méthod., Vers. i, p. 323), transferred Müller's species to the genus Bulimus. He cited Lister's fig. 14 and all three, I, L, N, of Gualtieri; at the same time he gave as synonym the Turbo fasciatus of Pennant, and this with his dimensions, "Sa longueur est de quatre lignes et demie, et sa largeur au bas est du moitié moindre," showed that he, too, had the same shell in mind as Müller.

1 Chemnitz (Syst. Conch. Cat., vol. ix, 1786, p. 190) suggested its identity with his Helix cretacea, etc. (pl. cxxxvi, f. 1263, Nos. 1-4), to which Gmelin afterwards (Linn. Syst. Nat., ed. 13, i, pt. vi, 1791, p. 3655) gave the name Helix carinula. Potiez \& Michaud (Galerie Moll., i, 1838, p. 144) query its identity with their Bulimus hieroglyphicus, and this is quoted by Beck (Index Moll., 1837, p. 63). Pfeiffer (Mon. Helic. viv., ii, 1848, p. 124) placed Bulimus barbarus, Linn., next to $B$. obscurus and gave as synonyms $B$. jeannoti, Terv., and B. ierverii, Forb. Later, however (op. cit., vi, p. 63), he made $B$. jeannoti the species. Menke, who discussed the whole question in 1845 (Zeitschr. f. Malak., 1845, pp. 29-30), pointed out that hieroglyphicus had nothing in common with jeannoti, and concluded that while it might be assumed with confidence that Helix barbara, Linn., was a Bulimus, the species was yèt doubtful; and that it was desirable that conchologists who in future might have more abundant Algerian material should not lose sight of the opportunity of solving the question. 
Draparnaud, in 1801 (Tabl. Moll. France, p. 68), first described two kindred forms as Bulimus acutus and B. ventricosus. The name of the first was evidently taken from Bruguière. The dimensions and the figures cited, Gualtieri's "I" and Lister's " 14 ", show that this again was the form we have in England and identical with Müller's and Bruguière's. In the synonymy Draparnaud cited with a "?" Helix barbara, Linn. This last reference is omitted in his later "Histoire".

In illustration of his B. ventricosus Draparnaud cited Gualtieri's figures L and N, whilst in synonymy the Helix acuta, Müller, and Bulimus acutus of Bruguière appear. ${ }^{1}$

Now by this synonymy did Draparnaud mean to imply that without specifically mentioning it he adopted Bruguière's name for the one form and merely cited Müller and Bruguière under the other to show that they had, in his opinion, included the two forms under one name? The following sentence under Bulimus ventricosus in the "Tableau", but omitted from the "Histoire", seems to show that he did: "Coquille plus courte et plus ventrue que la précédente, avec laquelle il paroît que les conchyliologistes l'ont confondue."

Moreover, Draparnaud was hardly likely to have overlooked the fact that his predecessors had cited Lister's fig. 14 as he did, and that their dimensions tallied with his.

In our opinion there was nothing that would justify the inclusion in its entirety of the Bulimus acutus of Müller and Bruguière as a synonym of Draparnaud's B. ventricosus

This seems to have been the mature view of Férussac, for although in the "Concord Systématique" at the end of his " Essai ", 1807 (pp. 120-121), he made Bulimus ventricosa [sic] the equivalent of Helix acreta, Müller, and Bulimus acuta [sic] the synonym of Helix barbara, Linn., when he wrote his "Tableau Systématique de la famile des Limaçons" in 1821 we find (Jan. ed. p. 56, June ed. p. 52), under Helix (Cochlicella) :

No. 377 ventrosus, nobis [corrected p. 74 (or 70) to ventrosa].

Bulimus ventricosus, Draparnaud.

Helix acuta, Müller.

No. 378 acuta, Müller.

Helix bifasciata, Pulteney.

Turbo bifasciatus, Pennant.

Bulimus acutus, Bruginière.

No. 379 barbara, Linné, etc.

"... Rien ne prouve que cette espèce soit la précédente."

1 Draparnaud further queried (p. 69) whether the Helix ventricosa, Müll., were only a variety of this species. Moquin-Tandon, however (Hist. Moll. France, ii, p. 279 , note), stated that it was the young of Bulimus obscurus. 
He thus inferred that Müller had included two forms under his acuta, whilst he overlooked the fact that Bruguière must, then, equally have done the same, and inclined to the opinion that barbara was distinct.

This disposition of the two forms now in question was followed by all the more noted French conchologists, such as Lamarck, Dupuy, and Moquin-Tandon.

Risso, however, in 1826 (Hist. nat. Europ. mérid., iv, p. 77) raised Férussac's Cochlicella to the rank of genus, adopted that author's ventrosa, but proposed the new name of meridionalis for Müller's acuta. Bourguignat, with his characteristic love of reviving dubious names, in 1864 (Malac. Algérie, i, p. 286), and again in 1868 (Hist. Malac. Tunis, p. 25), sought to identify Draparnaud's ventricosa with Linné's barbara.

On the other hand, in 1883, Fagot, in an entirely superficial paper (Glanages Malac., iii, pp. 29-32), in which he completely ignored the figures cited by the original authors, reverted to Férussac's abandoned synonymy of the "Essai" and adopted outright Helix barbara, Linn., for the Bulimus acutus, Drap., and took Helix acuta, Müll., for the Bulimus ventricosus, Drap. ${ }^{1}$

This reading was subsequently followed by Westerlund in 1889 (Fauna Paläarct. Region, ii, p. 366), by Connolly in 1912 (Ann. S. African Mus., xi, p. 157), by Caziot (Feuille Jeunes Nat., xliii, p. 160), and Germain in 1913 (Moll. France, pp. 118-119), whilst Pilsbry in 1895 (Man. Conch., ser. II, vol. ix, p. 264) made acuta, Müll., a synonym of barbara, Linn., and accepted $H$. ventricosa, Drap., with "ventrosa, auct.", and bulimoides, Moq., as synonyms.

Draparnaud was, however, forestalled in the use of the name Bulimus ventricosus by Bruguière in 1792 (Ency. Méthod., Vers, i, p. 363), so that Férussac's ventrosa displaces it for the French shell, since Moquin-Tandon's objection to the name (Hist. Moll. France, ii, pp. 279-80) does not seem valid in the light of present rulings, and his substituted name of bulimoides consequently falls into synonymy.

\section{Helix subrufescens, Miller, vice Helix fusca, Montagu.}

Unfortunately another well-known name in British non-marine Mollusca has to be changed. Montagu's appellation of Helix fusca (Test. Brit., 1803, p. 424) was anticipated by Poiret (Coq. Aisne, 1801 , p. 69), who applied it to what proves to be a colour variation of Helix nemoralis, Linn. Gray's Helix (Zenobia) corrugata (Med. Repos., xv, 1821, p. 239) being a nomen nudum, the next name on the list, Helix subrufescens of Miller (Ann. Phil., N.s., ii, p. 43), has to be

1 Webb \& Berthelot in 1833 (Ann. Sci. Nat., xxviii, p. 317) had adopted Helix acuta, Müll., with Bulimus ventricosus, Drap., as synonym; but this was corrected by Orbigny in the molluscan portion of the "Hist. Nat. Illes Canaries ", $1839, \mathrm{p}, 67$, to Bulimus ventricosus, Drap. 
accepted. The correct generic name is at the moment of writing sub judice.

\section{Helix hammonis and Turbo bidentatus of Ström.}

In his "Beskrivelse over Norske Insecter. Förste Stykke" (Det Trondheim. Selskabs Skrifter. Dl. iii, 1765) Ström names and inadequately describes and figures certain molluses. All trace of these seem to have been lost, but two of his names have of late been utilized in nomenclature, though, as we think, without justification.

His Helix hammonis (tom. cit., p. 435, pl. vi, f. 16) may well have been the fry of some larger species, as his $H$. domestica (tom. cit., p. 435 , pl. vi, f. 15) obviously was. The older writers, who are more likely to have known what he meant, differ in opinion from the later ones, who could have had no other evidence to go upon save the original author's imperfect diagnosis and figure. Thus Müller in 1774 (Verm. Hist., ii, p. 32) gave it as a synonym for his own Helix [Polita] nitida. He was followed in this by Fabricius in 1780 (Fauna Groenlanica, p. 389), and, of course, by Gmelin in 1791 (Linn. Syst. Nat., ed. 13 , i, pt. 6 , p. 3633 ), who cited it under $H$. nitens [= nitida, Müll.]. Beck in 1837 (Index Moll., p. 6) followed suit, but with a "?" Forbes \& Hanley likewise in 1852 (Hist. Brit. Moll., iv, p. 39) adopted this view. Gray in 1857 (Turton's Manual, new ed., p. 96) also recorded it under this species, which, however, he called Zonites lucidus.

Von Martens in 1856 (Malak. Blätter, 1856, p. 81) seems to have been the first to venture a new conjecture as to the identity of Ström's shell, and referred it to $H$. pura, Alder (cf. Pfeiffer, Mon. Helic. viv., iv, 1859, p. 83).

In 1864 Mörch (Synop. Moll. Danicæ, p. 13) treated Ström's name as valid, and placed the Helix radiatula of Alder as a synonym. His conclusion was adopted by Pfeiffer in 1868 (Mon. Helic. viv., v, p. 147) and by Westerlund in 1871 (Nova Acta Soc. Sci. Upsala, ser. III, vol. viii, No. 1, p. 25) under the name Zonites (Hyalinia) hammonis (Ström).

All these divergent views are obviously so purely speculative that it is clear Ström's name must be definitely rejected.

Ström's Turbo bidentatus appears to have had an equally chequered career. Müller in 1774 first made it a synonym of his Helix bidens (Verm. Hist., ii, p. 116), and then a little later on (p. 119) under his Helix perversa (which includes as the young forms what we now know as Balea perversa, and as adult the Clausilia rugosa of Draparnaud) wrote "Ström definitione Linneana seductus precedentis pullum perversam, adultum vero novam speciem sub nomine bidentatce finxit." Gmelin, of course, copied this dual entry (Linn. Syst. Nat., ed. 13 , i, pt. 6 , pp. 3609 and 3610 ). Then the matter seems to have rested till Mörch in 1864 (Synop. Moll. Daniæ, p. 30) revived the name 
as a distinct species, followed by $C l$. dubia, Drap., with $C l$. rugosa, C. Pfr., as synonym thereof, but gave no reasons for his procedure: Mörch was followed as usual by Westerlund in 1871 (Nova Acta Soc. Sci. Upsala, ser. III, vol. viii, p. 78). No other authority, not even Boettger (Clausilienstudien, 1877) appears to have given currency to Ström's name.

Since the original description and figure might equally well apply to such other form as $\mathrm{Cl}$. parvula, Studer, it is best discarded.

The species to which it has been applied will therefore in future be known under Draparnaud's name of $C l$. rugosa (1801), this having priority over $\mathrm{Cl}$. nigricans, Maton \& Rackett (Trans. Linn. Soc., viii, 1807, p. 180). It has been generally overlooked that Maton and Rackett's citation in synonymy of "Pultney" refers not, as has been assumed, to the original editions of the "Catalogues" (1799), in which the name in question does not appear, but to the then forthcoming second edition in 1813, which Rackett was editing, and for which the plates had been prepared.

\section{In re Fitzinger.}

An eccentric genius, like Rafinesque, whom he resembled in that some of his work stands, Fitzinger was obviously very careless in the preparation of his manuscript and totally neglectful as regards its printing. How else can the following errors be accounted for in his classical "Systematisches Verzeichniss der in Erzherzogthume Oesterreich vorkommenden Weichthiere" (Beitr. Landesk. Oesterreich., iii, 1833, pp. 88-122)?

Thus at the bottom of p. 98 we find "Gonyodiscus perspectivus, Mihi " as a new name for Helix perspectiva, Mühlfeld; $H$. rotundata, Pfeiffer; and Helicella rotundata, Fér.; whilst at the top of the next page we have "Discus rotundatus, Mihi" for Helix rotundata, Argenville \& Drap.; Helicella rotundata, Fér. Granted that he drew a distinction between the Helix rotundata of Pfeiffer and those of Argenville and Draparnaud, he can really not have intended to place the Helicella rotundata, Fér., at one and the same time in two different genera. Is it not rather likely that he wrote Discus at first, and subsequently changed it to Gonyodiscus (which, of course, should be Goniodiscus), making the correction on the first entry and expecting the printer to carry it through, which was not done.

The next oversight occurs a few lines down. The last entry under Discus being "D. cristallinus, Mihi" for " Helix crystallina, Müller \& Draparnaud", this is immediately followed by "Vitrea diaphana, Mihi" for "Helix crystallina, Drap.; H. diaphana, Studer", etc. This second introduction of Draparnaud's species as an equivalent for diaphana is the more amazing since the latter does not occur in France. The two forms crystallina and diaphana are so absolutely inseparable generically and so unlike the other species put under Discus, that the error is obvious. 
Again, on p. 100, under Oxychilus we see the species usually referred to the subgenus Polita (with the added blunder of referring Helix nitida, Müller, to both "O. lucidus" and " $O$. nitidulus var. nitens") having appended to them "O. ericetorum" and its "var. cespitum", both for the well-known Müllerian species. It is clear these were intended to form part of the following "Helicopsis" with its sole species "striata" and supposed synonyms intersecta and fasciolata, Poiret, caperata, Mont. Unfortunately, the name Oxychilus is rendered untenable by the earlier Oxycheila of Dejean, 1825, for Coleoptera.

The final slip is on p. 111, where under Anisus, for Planorbis complanatus, Drap., carinatus, Müll., and marginatus, Drap., $A$. vortex, Müll., is included, which could not have been intended to be separated from the immediately following "Planorbis spirorbis, Müller". Fitzinger probably borrowed his Anisus from Studer, 1820, who employed it for Planorbis with Physa, whilst his name as circumscribed is shut out by Dejean's use of it in 1821 for Coleoptera.

\section{The type of Ancylus, Geoffroy.}

It seems to have been generally overlooked that Geoffroy, when he founded the genus Ancylus (Traité Coq. Paris, 1767, p. 122), cited but one species, and that one (p. 124) the Patella lacustris of Linné. We think we have established (Journ. Linn. Soc. (Zool.), xxxiv, 1920 , p. 210) that this was the form which came into Beck's group Acroloxus (= Velletia, Gray), consequently Acroloxus becomes a synonym of Ancylus [s.s.].

The kindred British form fluviatilis, Müll., it is universally agreed, must be placed in a distinct genus, since âmong other differences is a sinistral animal, whereas lacustris is dentral, so that recourse must be had to the subgeneric name of Ancylastrum, proposed by Bourguignat in 1853 (Journ. de Conchyl., iv, p. 63), and that name must now be raised to generic rank.

Bourguignat's procedure in the same paper (p. 187) in replacing Müller's trivial name of fluviatilis by " simplex, Buc'hoz", cannot be sustained. Buc'hoz was not a binominal author, and there is nothing to show that his "Lepas simplex", etc., was in any way related to Müller's mollusc.

\section{On Bulinus of Adanson.}

The recent tendency to revive Adanson's old name of Bulinus, or, as amended by Oken, Bullinus, especially in medical literature dealing with Bilharzia, renders it desirable to once again point out that the name is not available, and further that its use especially in its present erroneous application to aquatic mollusca in widely separate regions is misleading and mischievous both to medical and geological science.

Adanson (Hist. Nat. Sénégal, 1757, Coquillages, p. 5) bestowed this generic name on a diminutive and probably immature physoid 
shell, $3.5 \mathrm{~mm}$. in length, in which the mantle did not, he says (p. 6), protrude beyond the margin of the shell, thus differentiating it from true Physa. Adanson's shell has remained indeterminate.

O. F. Müller, in 1781 (Geschichte der Perlen-Blasen, "Der Naturforscher," xv, pp. 1-20), took up this derelict, pre-Linnean name (p. 6), added the trivial name of senegalensis to Adanson's shell, and associated with it the three supposedly kindred molluses from his "Vermium Historia", viz. Planorbis bulla (which he rechristens B. perla), Pl. turritus, and $P l$. gelatinus. Of course, the adoption of Adanson's name involves the acceptance of his shell as the type of the genus. Since, however, that is indeterminate, this postLinnean revival of the name is rendered nugatory. But for that Bulinus, Müller, 1781, would have precedence of Physa, Draparnaud, 1801.

Oken, in 1815 (Lehrb. Naturgeschichte, iii, abth. 1, p. 302), practically followed Müller, but emended Adanson's name to Bullinus (out of respect, apparently, to its Latin derivation), and added to the genus Patella fluviatilis, thus making confusion worse confounded. His name is equally invalid.

The name Bullinus next occurs in a quaint sale catalogue of the effects of Bishop 0. Fabricius, entitled "Fortegnelse over en ... Bogsamling . . . tillegemed en betydelig Deel Naturalier, hvoriblandt en Conchyliesamling, afgange Biskop Fabricius's ... som ved auction ... forstkommende", etc., which was published in Copenhagen in 1823. On p. 71 of this book Bullinus fontinalis, hypnorum, and terebellum are cited.

Beck in 1838 (Index Moll., p. 116), apparently following Müller, employed Adanson's name, distinguishing two subgenera : 1 Aplexa, Fleming, for A.hypnorum (L.) B., elongata, Say, etc., and 2 Bulinus, B., for B. fontinalis (L.) B., contortus, acutus (Drp.) B., senegalensis, O. Müll., etc.

Meantime Ehrenberg, in 1831 (Symbol. Phys. Anim. Evert. [p. 87]), had established the genus Isidora for certain Egyptian and Syrian physoid molluses.

In 1869 both Dohrn (Malak. Blätt., p. 18) and Von Martens (Malak. Blätt., p. 213) questioned whether Isidora might not be allied to Adanson's "Bulin". A suggestion that Jickeli in 1874 (Nova Acta K. Acad. Leop.-Carol., xxxvii, No. 1, p. 202) considered a very probable one.

H. Adams, in 1861, when describing certain shells in the Cuming Collection (Proc. Zool. Soc. Lond., 1861) created (p. 143) a new subgenus, Ameria, of Physa, for certain forms from Australia with flattened and angulated whorls, carinated at the posterior part.

Fischer, in 1883 (Manuel Conchyl., p. 509), accepting pre-Linnean writers, revived Adanson's name of Bulinus for a genus distinct from Physa, and placed in its synonymy Isidora of Ehrenberg, with Gray's Diastrophia (Turton's Manual, 1840, p. 16), which was established for the European Physa contorta, Michaud. 
Cooke, in 1889 (Proc. Zool. Soc. Lond., 1889, pp. 136-43), discussing the sinistral shells from Australia that had been referred to Physa, concluded that they were, judging by the radula, generically identical with Isidora, and, evidently unaware of the history of the name detailed above, followed Fischer in accepting Adanson's Bulinus for them. In 1895, however (Cambridge Nat. Hist., iii), Cooke abandoned the name Bulinus in favour of Isidora. He seems to have overlooked the fact that Adams' name Ameria, were his conclusions correct, would have priority.

A comparison of Jickeli's figures of the radulæ of Isidora, on which Cooke relied, with those which the latter author gave of the Australian shells shows the existence of certain differences which lead us to think that he would nowadays be disposed to consider sufficient to differentiate the Australian physoids from Isidora, and as he pointed out that though Adams founded this Ameria on keeled examples " every gradation of keeling is observable . . . and occasionally the same species is indifferently keeled or perfectly smooth ", would further be disposed to accept Adams' name for the Antipodean shells, whilst we are not sure but that he would separate off the New Zealand from the Australian forms. All this Dr. Cooke now assures us in a recent letter is in effect the case.

Tate in 1896 (Rept. Horn Exped. Centr. Austral., ii, p. 212) proposed the name Isidorella for certain other Australian physoid forms allied to the Physa newcombi, Ad. \& Ang., in which there is no columellar fold.

Our conclusions, therefore, are : that the only group to which the name Bulinus could have been correctly applied would have been to that which bears, and should retain, the name of Physa; that the Egyptian shells which play the part of host to Bilharzia should be known as Isidora; that their Australian kindred should retain the names Ameria and Isidorella, the New Zealand offshoot receiving a fresh name; whilst the fossil Physa prinsepii, Sowb., which Annandale has lately referred to Bullinus (Journ. and Proc. Asiatic Soc. Bengal, N.S., xvi, 1920 , p. xxiv) is most likely a distinct type. ${ }^{1}$

\section{VIVIPARUS.}

The occurrence in the Linnean Collection of the numbered specimens of his Helix vivipara and the receipt from Dr. Johansen of plesiotypes of Müller's Helix fasciata has put the identity and nomenclature of the two British species beyond question.

How it came about that for a time there was considerable confusion, and its probable explanation, is, however, of interest, and we think

1 Dr. Annandale writes: "From a purely technical point of view I agree that Isidora is preferable to both Bullinus and Bulinus, but Bullinus has obtained currency in medical literature, and I regard it as a nomen conservandum." Thus does error seek ever to justify itself ! 
can be explained as follows. The trouble seems to have arisen with Draparnaud, the first after Müller, we believe, to distinguish the two species, for his "Histoire", being the first well-illustrated book, was both largely used and followed.

In his "Tableau" (1801, p. 40) Draparnaud clearly reversed the two species as we now understand them. Not only is this shown by his measurements, but by the statement under Cyclostoma achatinum, "La coquille est ... plus allongée que la précédente [C. viviparum $]$; et la suture de la spire est moins profonde".

When he wrote the "Histoire" (1805), however, he would seem from his text to have changed them over just as he did his Helix lucida and $H$. nitida, for, though the dimensions are omitted and the descriptions of the two species annoyingly vague, he does remark of Cyclostoma viviparum (p. 35) "Spire composée de six tours convexes et très-distincts", and of C. achatinum (p. 36) "Spire de 6 tours convexes ; suture très-marquée", which clearly points the latter being the Helix fasciata of Müller. His synonymy, too, bears this out. The figures, on the other hand, which are not cited in the text, are numbered in accordance with the description of the "Tableai" ".

Now seeing that there were errors of lettering on other of the plates, as admitted and blamed to the engraver in the explanation to plate $\mathrm{x}$, and cited in the "errata" for plate $\mathrm{v}$, whilst as pointed out first by Brard (1815) for plate vi (where 12 should be neglecta and 16 and 17 should be ericetorum, it does not seem too much to postulate that a similar error was committed in the explanation of plate $i$, and that the "viviparum" to fig. 16 should be exchanged with the "achatinum" to fig. 18. This correction effected Draparnaud's text and figures bezome harmonious.

Except Brard, who failed to differentiate between the two species and did not therefore deal with the question, Draparnaud's successors seem to have overlooked his descriptive text and fastened their attention on his figures.

Millet (1813) accepted Draparnaud's synonymy, but did not cite his figures, whilst evidently following them as named in the explanation and giving his own amplified and perfectly clear descriptions. At the same time, objecting to the trivial name viviparum as not indicating a peculiarity of the species, he proposed instead "contectum". In the second edition (Actes Soc. Linn. Bordeaux, vi, 1833, p. 134) he adopted Paludina as the generic name for the two species, and abandoning his name of contecta made it a synonym for "P. vivipara, Lam." In the third edition (Ann. Soc. Linn. Maine \& Loire, i, 1854, pp. 304-305 [separate pp. 56-57]) he changed the generic name to Vivipara and the specific names to "vulgaris, Lam." and "fasciata". Since Lamarck did not, so far as ascertained, ever use the name here attributed to him, whilst Dupuy, who follows next in Millet's synonymy, did, we are inclined to believe that the 
insertion of the "Lam." was a "printer's error", a supposition which the setting under fasciata tends to confirm.

C. Pfeiffer (1821), Lamarck (1822), Turton (1831 and 1840), Brown (1837-44 and 1845), all followed Draparnaud's figures in their nomenclature, and the correct allocation of the species was not restored till Forbes \& Hanley (1850) did so more by accident, as their synonymy shows, than by design. Their vivipara corresponded to Linné's, but, unaware of Millet's work, they proposed the trivial name of listeri for the other species. Moquin-Tandon followed on the lines of Forbes \& Hanley, but employed Millet's name of contectum in lieu of listeri, and this arrangement was conformed to by Jeffreys and Reeve, and continued by later writers down to quite recent times. Only Bourguignat in 1862 (Rev. \& Mag. Zool., 1862, pp. 110-112) confused the species and synonymy. Locard, in his "Ipsa Draparnaudi Conchylia" (1897) detected the discrepancy between Draparnaud's text and figure in the case of "Cyclostoma achatinum", but misled as to the "Nerita vivipara" of Müller and its identity with Linné's Helix vivipara, failed to realize the true solution, as we think, of the confusion. 


\section{$2 \mathrm{BHL}$ Biodiversity Heritage Library}

Kennard, A. S. and Woodward, Bernard Barham. 1920. "NOMENCLATORIAL NOTES RELATING TO BRITISH NON-MARINE MOLLUSCA." Proceedings of the Malacological Society of London 14, 77-90.

https://doi.org/10.1093/oxfordjournals.mollus.a063725.

View This Item Online: $\underline{\text { https://www.biodiversitylibrary.org/item/95719 }}$

DOI: https://doi.org/10.1093/oxfordjournals.mollus.a063725

Permalink: https://www.biodiversitylibrary.org/partpdf/202443

\section{Holding Institution}

Smithsonian Libraries

\section{Sponsored by}

Smithsonian

\section{Copyright \& Reuse}

Copyright Status: Public domain. The BHL considers that this work is no longer under copyright protection.

This document was created from content at the Biodiversity Heritage Library, the world's largest open access digital library for biodiversity literature and archives. Visit BHL at https://www.biodiversitylibrary.org. 